Global Conferences Series:

Sciences and Technology (GCSST), Volume 3, 2020

The $1^{\text {st }}$ International Conference on Education, Sciences and Technology

DOI: https://doi.org/10.32698/tech3251

\title{
Tumbutana" As an Oral Tradition of Hospitality and Character Education for the Arfak Tribes of West Papua
}

\author{
Mayske Rinny Liando ${ }^{1}$, Veroska JS Teintang ${ }^{2}$, Donna Sampaleng ${ }^{3}$ \\ ${ }^{1}$ UniversitasNegeri Manado \\ ${ }^{2}$ Member of Oral Tradition Association \\ ${ }^{3}$ Co- Program of Christian Education; Sekolah Tinggi Theologi IKAT \\ ${ }^{4}$ Head of LembagaPenelitiandanPengabdianMasyarakat
}

\begin{abstract}
This research is a qualitative research with an ethnographic approach to find out how Tradition can be used in Character Education. This research was conducted in the Arfak Mountains region of West Papua, which has a dance tradition "TumbuTana" as a hereditary cultural heritage. The Arfak tribe often carries out the "Tumbutana" tradition in every joint activity involving the wider community. This is one form of politeness and friendliness from the Arfak tribes. Research with a cultural approach is very interesting with the study of digging deeper into rules, values, narration of song lyrics and so on so that understanding the tribal tradition will be able to find the key to character education to build a society that is cultured and loves diversity. Indonesia, which is inhabited by many indigenous tribes, provides a variety of regional dances that are passed down from generation to generation. From this study it was found that traditional values have a very positive influence on the character education of the large tribe of Arfak. The Tumbu Tanah tradition provides education of character values as follows: Faithful; Honest; Open; care to each other; obedient; empathy; respect for the elder; respect for others; peace and responsibility
\end{abstract}

Keywords:Tumbu Tanah; Oral Tradition; Hospitality; Character Education

\section{Introduction}

The Indonesian nation is an inseparable part of a civilization. Indonesia has become a civilized nation and has its own civilization in accordance with its character and identity. The Indonesian nation has the potential to realize a more elegant, polite and characterized civilization based on science and technology and change itself. Therefore, to realize this education is the most appropriate answer to make it happen. Education has a central role in discovering and directing a nation's civilization, because one of the principles of education is the development and development of humanity.

Education in a broad sense is also a cultural process. Humans are formed according to their learning potential in order to become a full member of the community who can live and practice their potential, both individually and together with other members. Practically, education is a process of delivering culture or a civilization process that aims to make people possess certain skills, knowledge, attitudes, values, and behavioural patterns. Regarding broad and practical understanding, it can be said that

Copyright (C) 2019, the Authors. Published by Redwhite Press.

Page | 162

This is an open access article under the CC BY-NC license

(http://creativecommons.org/licenses/by-nc/4.0). 
education aims to transform cultural values, through education in the household (family), in society, and in school, which shows what is good in society (Sagala, 2006: 227) .

The target of the education unit is basically students as part of community members with a criterion of cultural values as desired by community members. Education aims not only at the process of cultural transfer or transfer of knowledge, but also at the same time as the transfer of value. This means that education, in addition to the process of linking and transmitting knowledge, is also concerned with the process of development and formation of the personality or character of society.

\section{Theoretical study}

\section{Character Education}

Character education is value education, character education, moral education, and character education that aims to develop the ability of students to make good and bad decisions, maintain what is good and realize that goodness in everyday life with all my heart. A person's character cannot be built for a moment and by a particular education. The character itself comes from Greek which means "to mark" or marks and focuses on how to apply the value of goodness in the form of action or behaviour, so that people who are dishonest, cruel, greedy and other bad behaviour is said to have bad character. Conversely, the person whose behaviour is in accordance with moral rules is called noble character. David Elkind\& Freddy Sweet Ph.D. (2004), argues that character education is a deliberate effort to help people understand, care about, and act upon core ethical values. When we think about what we want for children, it is clear that we want to be able to judge what is right, care about what is right, and then do what they believe to be right, even in the event face of pressure from without and temptation from within.

Character is a way of thinking and behaving that is characteristic of each individual to live and cooperate, both within the scope of family, society, nation and state. Individuals who have good character are individuals who can make decisions and are ready to account for each consequence of the decisions he makes (Suyanto, 2012). According to Musfiroh (UNY, 2008), character refers to a set of attitudes, behaviors, motivations, and skills (Ministry of National Education, 2010). So it can be concluded that through education we can preserve and preserve culture by the process of transferring learning knowledge of attitudes and skills including character education. Both are very closely related because they complement and support each other. The purpose of education is to preserve and always improve the culture itself, with education we can transfer the culture itself from generation to generation. And also we as a society aspire to the realization of a better society and culture in the future, so our own education must be better.

According to Ki HajarDewantara (1977: 14-15) the notion of character education is the efforts to advance the growth of character (inner strength, character), mind (intellect) and the child's body; in the sense that Taman Siswa should not be separated into parts so that we can advance the perfection of life, namely the life and livelihood of the children we educate in harmony with their world. Based on this understanding can be underlined in the words "advance the growth of character (inner strength, character), mind (intellect) and body of the child". Ki HajarDewantara as the father of education in Indonesia also stressed that spiritual / mental strength or character is as important as one's intellectual needs and health. Adequacy of the strength of character, intellectual, and physical health which can then be used as a provision for someone to achieve the perfection of life. 


\section{Oral Tradition}

Understanding Oral Tradition is one type of cultural heritage of the local people whose inheritance is carried out verbally. According to Jan Vansina, the notion of oral tradition is "oral testimony transmitted verbally, from one generation to the next one or more" (testimony passed down orally from generation to generation). Oral tradition appears in the environment of oral culture of a society. Those who do not know the writing, in the oral tradition contained elements of historical events, moral values, religious values, customs, imaginary stories, proverbs, songs, and spells of a society.

Often the notion of oral tradition is considered the same as folklore. However, both elements of culture actually have differences. Folklore consists of oral and half oral folklore and the process of dissemination is carried out orally by word of mouth or by other means. On the contrary, oral tradition is one type of oral folklore and its inheritance process is only carried out verbally. Therefore, folklore is broader in understanding than oral tradition. The form of oral tradition consists of folk tales, folk puzzles, folk proverbs, and folk songs, while folklore includes all kinds of oral traditions, folk dances, and folk architecture.

\section{“TumbuTanah" Dance}

Tumbu Tanah", also known as the snake dance, is a symbol of togetherness that is inseparable from one another, both from the side of the family, the clan, the ancestral ancestry. Tumbu Tanah dance is held during special events such as welcoming, inauguration, custom settlement, etc. This dance is a place to bring together other families / strengthen kinship. Any guest or community who is and wants to be involved in dancing is welcome to join.

The lyrics sung during the dance of the snake dance (Growing the Land) follow the form of the event that is celebrated, whether for victory in a tribal war, or the appointment of the highest official, or marriage event, so that the rhythm of the voice and the tone of voice in praise are adjusted. The song that is sung contains poetry about love, nature, the figure of the leader who is idolized and also the deeds of God (Spiritual).

$$
\begin{gathered}
\text { Example of Lyrics: } \\
\text { MansarDominggusMandacanbisisaibatma,,,bisisaiSijma= } \\
\text { bapaDominggusMandacanko yang bicaradanko yang lakukan... Kita ikuti yang } \\
\text { bapasampaikan }
\end{gathered}
$$

The leader of this dance is a leader, a traditional elder (Head of Tribe), or who is appointed to pronounce a long narrative in the first part with a fast rhythm to collect, after that it is followed by praise or songs that will be accompanied together

Tabel1 Element of Tumbu Tanah

\begin{tabular}{|l|l|l|l|}
\hline \multicolumn{2}{|c}{ NO ELEMENT } & \multicolumn{2}{c|}{ DESCRIPTION } \\
\hline Leader & Group Leader & $\begin{array}{l}\text { People who lead the } \\
\text { song and be spoke } \\
\text { person }\end{array}$ & Obey the Leader \\
\hline Songs & Lead by the Elder one & $\begin{array}{l}\text { The leader will say the } \\
\text { words and all } \\
\text { participant will repeat it }\end{array}$ & $\begin{array}{l}\text { Saying the spiritual } \\
\text { words to show their } \\
\text { truly respect and }\end{array}$ \\
\hline
\end{tabular}




\begin{tabular}{|c|c|c|c|}
\hline & & $\begin{array}{l}\text { again as a respond and } \\
\text { they must jump and } \\
\text { moving around }\end{array}$ & faithful \\
\hline Participant & Man, Woman, Children & $\begin{array}{l}\text { Participants (circular } \\
\text { position and arm in } \\
\text { arm) consist of women, } \\
\text { men, and children }\end{array}$ & Unity and Harmony \\
\hline Move & $\begin{array}{l}\text { Jump; Standing Up, } \\
\text { Look Around, }\end{array}$ & $\begin{array}{l}\text { Move in the same } \\
\text { direction in command }\end{array}$ & Unity and Harmony \\
\hline Attribute & $\begin{array}{l}\text { Attribute for Man and } \\
\text { Women }\end{array}$ & $\begin{array}{l}\text { Arrows; Fabrics, } \\
\text { Necklaces, Machetes, } \\
\text { Soil (Mud), Plants, } \\
\text { Spears, etc } \\
\text { The Headband; Noken } \\
\text { and Traditional Clothes }\end{array}$ & As a Identity of Arfak \\
\hline Sound & No Music & $\begin{array}{l}\text { The Sound will come } \\
\text { up from every Jump } \\
\text { and Step. }\end{array}$ & Be a Natural \\
\hline
\end{tabular}

kondolongit (2016: 44) describes Every Tumbu Tanah dance movement has symbolic meanings related to religious systems, their social environment and their natural environment. Their basic movements are dominant in foot and hip movements while hand and head movements are only to compensate for the dancer's body. Ground turtle dance is a type of dance that is known by almost all tribes in the region of the head of Papuan birds and each tribe calls this dance according to its own language. The aspect of art that seems to have similarities between the people of Arfak, is dance, which has traditionally been around since their ancestors and passed down from generation to generation until now. There are 3 (three) types of ground tasting dances known by the people of Arfak, namely Tumbu Tanah victory dance in war, looking for a mate and welcoming guests. Whereas the aspects of the type of song or poem include diun, nihetduwei and isiap. The basic motion of this dance is in the people of Arfak who have been there for a long time until now which is jumping up and down while stomping on the ground and holding hands. The formation used is still up to now, which is a longitudinal and half-circular formation and full circle. The ground-dancing for the people of Arfak has very high social, economic and cultural values because it relates to the historical aspects of their origins, religion and other cultural elements. Besides that in the movement and formation of this dance also has ethics, good manners, respect for the ialin and the association of young people. 


\section{Methodology of Research}

This study uses a textual approach that examines the content of certain elements in the elements of the Tumbu Tanah tradition in the culture of the great tribe of Arfak in the people of West Papua. By using a qualitative approach that is descriptive because the workings and data obtained are in the form of document data; interviewing traditional leaders, carrying out the traditional dance of Arfakdirectly and processed with qualitative logic. The research data was collected through repeated involvement and scrutiny every time the tradition dance of Arfakwas carried out to gain an understanding of the value of character education and then followed by the work of recording the findings of these values. The next step is to process and analyze the data collected. The instruments used in research are human instruments or researchers themselves with note paper and stationery. The collected data is then analyzed by content analysis or content analysis techniques. According to Endraswara (2012: 81), the main purpose of content analysis is to make inference a message of cultural phenomena.

\section{Discussion}

Humans and society as objects of education in their growth do not change when they are somewhere and then elsewhere. All the life processes he experiences, whether at home, in the community or at school, will fill the scheme in his mind. That will color his behavior and eventually become a value system in his life. This experience will shape itself as a member of society which is realized by thinking, speaking, associating, analyzing, and so on. Chaplin (1989: 179) says, experience (experience) is an event that has been experienced, the totality of current awareness, and knowledge or skills obtained from practice or business learning. An understanding of this experience starts from a simple form, namely an event that is experienced, to a complex that is the result of learning efforts. Some experts say that what is shown by a group of people is culture as stated by AB Taylor, that culture is a complex totality that includes knowledge, art, law, beliefs, morals, customs, and what abilities and habits are obtained people as members of society (Manan in Sagala, 2006: 222). This opinion is reinforced by Bouman who argues that culture is a way of life of a society (Ali, 1993). The behavior and creativity of the people who describe the culture are not just dances, songs, cultural prescriptions, or other artistic expressions, but also how the society thinks, analyzes, makes decisions, obeys the law, norms, ethics, all of which are seen as accumulated performance from the process of maturation and education in the family and in society through formal education in schools as a value system (Sagala, 2006: 223).

\section{Conclusion}

Tumbu Tanah is part of the oral tradition of the great Arfak tribe community which has been carried out for generations, from generation to generation. The Tumbu Tanah dance provides all descriptions of the characteristics of the Arfak tribe, which is very thick with attachments to one another. An illustration of character values contained in the procession of motion and narration.

Through this tradition, the process of transferring and transforming character values is so good that this tradition can become a bridge to the implementation of character education for children, families and society.

It can be concluded that the meanings contained in this oral tradition are as follows:

1. This dance unites and binds, marked by the position of the arms that are interrelated with each other.

2. Value of Sincerity. Communities introduce objects that exist as an inseparable element of society so that guests who come do not need to feel afraid and worried.

3. The Oral tradition about a value of politeness and openness of the people of the great tribe of Arfak. Everyone is considered a "guest who must be respected and welcomed by his arrival. The community is very open and friendly to receive visits 
4. Pride of the Arfak Mountains Arfak Great Tribe. The Papuan people are very proud of their nature so that every element in the tradition will always introduce its nature (land), often the land (mud) becomes a part that is anchored to guests in the hope that it will be very integrated with the Papuan people.

\section{References}

[1]. KementerianPendidikan Nasional. 2010. PanduanPendidikanKarakter. Jakarta; Kemdiknas.

[2]. Sagala, Syaiful. 2006. ManajemenBerbasisSekolahdanMasyarakat,

StrategiMemenangkanPersainganMutu. Jakarta: PT RakastaSamasta.

[3]. Endraswara, S. 2012. MetodologiPenelitianKebudayaan. Yogyakarta: GadjahMada University Press.

[4]. Hidayatullah, F. 2010. PendidikanKarakter: MembangunPeradabanBangsa. Surakarta: Yuma Pustaka

[5] L, Siany.,AtiekCatur B. (2009). KhazanahAntropologi 1: UntukKelas XI SMA dan MA, Jakarta: Depdiknas

[6]. Kondolongit, EY danSawaki Andi T; 2016 TARIAN TUMBU TANAH (TARI TRADISIONAL MASYARAKAT ARFAK DI PEGUNUNGAN ARFAK, PROVINSI PAPUA BARAT); BPNB Papua 